\title{
Stemphones, Novel Potentiators of Imipenem Activity against Methicillin-resistant Staphylococcus aureus, Produced by Aspergillus sp. FKI-2136
}

\author{
Nobuhiro Koyama, Tomoko Nagahiro, Yuichi Yamaguchi, Rokuro Masuma, \\ Hiroshi Tomoda, Satoshi Ōmura
}

Received: September 26, 2005 / Accepted: October 26, 2005

(C) Japan Antibiotics Research Association

\begin{abstract}
A fungal strain FKI-2136 identified as genus Aspergillus was found to produce potentiators of imipenem activity against methicillin-resistant Staphylococcus aureus (MRSA). Two new compounds designated stemphones B and $\mathrm{C}$ were isolated along with a structurally related known compound cochlioquinone D from the fermentation broth of the producing strain by solvent extraction, silica gel column chromatography and preparative HPLC. These compounds have a common tetracyclic quinone skeleton. Stemphone $\mathrm{C}$ potentiated imipenem activity against the MRSA 512 fold by decreasing MIC value of imipenem from $16 \mu \mathrm{g} / \mathrm{ml}$ to $0.03 \mu \mathrm{g} / \mathrm{ml}$.
\end{abstract}

Keywords stemphones, imipenem potentiator, methicillin-resistant Staphylococcus aureus, MRSA, fungal metabolite, tetracyclic quinone

\section{Introduction}

Methicillin-resistant Staphylococcus aureus (MRSA) is known as a major nosocomial pathogen which has also developed resistance to many other antibiotics. Moreover, MRSA has been reported to acquire resistance to the lastresort antibiotic, vancomycin $[1,2]$. These facts suggest that $S$. aureus would fully acquire resistance to vancomycin in near future. It is therefore increasingly important and necessary to find new antimicrobial agents and to devise new measures that are effective against MRSA infection.

Based on the new concept of "anti-infective drugs" developed by Ōmura [3], various potentiators of antifungal miconazole activity against $C$. albicans were discovered by our group [4 8]. It is expected that potentiators of imipenem activity against MRSA would, likewise, have application to the development of therapeutics against MRSA infection. During our screening for imipenem potentiators against MRSA from microbial origin, three structurally related active compounds were isolated from the culture broth of a fungal strain FKI-2136. One was identified as cochlioquinone D originally reported as an inhibitor of the root growth of the host plant seedlings such as ryegrass and rice [9], but the others were found to be new compounds designated stemphones B and C (Fig. 1). Stemphone (renamed stemphone $\mathrm{A}$ in this paper) previously reported as an inhibitor of the growth of Bacillus megaterium and Sarcina lutea [10] was not detected in the culture broth of strain FKI-2136. In this paper, the taxonomy of the producing strain, fermentation, isolation, structure elucidation and biological properties of stemphones are described.
H. Tomoda (Corresponding author): School of Pharmaceutical Sciences, Kitasato University, 5-9-1 Shirokane, Minato-ku, Tokyo 108-8641, Japan

Y. Yamaguchi, S. Ōmura: The Kitasato Institute, 5-9-1 Shirokane, Minato-ku, Tokyo 108-8642, Japan
N. Koyama, T. Nagahiro, R. Masuma, S. Ōmura: Kitasato Institute for Life Sciences and Graduate School of Infection Control Sciences, Kitasato University, 5-9-1 Shirokane, Minatoku, Tokyo 108-8641, Japan 


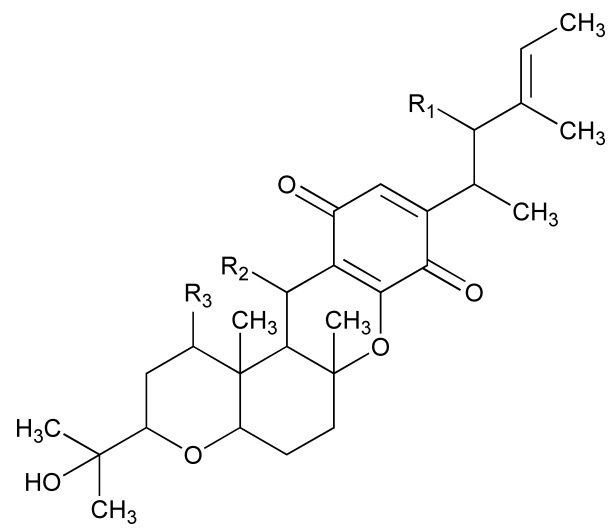

\begin{tabular}{lccc}
\hline & $\mathrm{R}_{1}$ & $\mathrm{R}_{2}$ & $\mathrm{R}_{3}$ \\
\hline Stemphone B & $-\mathrm{OAc}$ & $-\mathrm{OH}$ & $-\mathrm{OH}$ \\
Stemphone C & $-\mathrm{OAc}$ & $-\mathrm{H}$ & $-\mathrm{H}$ \\
Cochlioquinone D & $=\mathrm{O}$ & $-\mathrm{H}$ & $-\mathrm{H}$ \\
\hline Stemphone A & $-\mathrm{OAc}$ & $-\mathrm{OH}$ & $-\mathrm{H}$
\end{tabular}

Fig. 1 Structures of stemphones A, B and C and cochlioquinone D.

\section{Materials and Methods}

\section{Materials}

The following materials were purchased from commercial sources: Cloxacillin (ICN Biomedicals), cefazolin (Wako), vancomycin (Wako), tetracycline (Wako), ciprofloxacin (Wako), sulfate (Meiji Seika) and imipenem (Banyu Pharmaceutical). Erythromycin was isolated from microbial sources by our group.

\section{General Experimental Procedures}

Fungal strain FKI-2136 was isolated from a soil sample collected at Isigakijima Island, Okinawa Prefecture, Japan. This strain was used for production of stemphones. Kieselgel 60 (E. Merck) and SSC-ODS-7515-12 (Senshu Sci.) were used for silica gel and octadecyl silyl (ODS) column chromatography, respectively. HPLC was carried out using an L-6200 system (Hitachi). For detection of stemphones in culture broths, the samples (ethyl acetate extracts) dissolved in methanol were analyzed by an HP1100 system (Hewlett Packard) under the following conditions: column, Symmetry $(2.1 \times 150 \mathrm{~mm}$, Waters $)$; flow rate, $0.2 \mathrm{ml} /$ minute; mobile phase, a 20 -minute linear gradient from $60 \% \mathrm{CH}_{3} \mathrm{CN}$ to $100 \% \mathrm{CH}_{3} \mathrm{CN}$ containing $0.05 \% \mathrm{H}_{3} \mathrm{PO}_{4}$; detection, $\mathrm{UV}$ at $210 \mathrm{~nm}$. Under these conditions, stemphones $\mathrm{B}, \mathrm{C}$ and cochlioquinone $\mathrm{D}$ were eluted as peaks with retention times of $4.7,8.3$ and 6.7 minutes, respectively.

UV spectra were recorded on a spectrophotometer (DU640, Beckman). IR spectra were recorded on a Fourier transform infrared spectrometer (FT-710, Horiba). Optical rotations were measured with a digital polarimeter (DIP370, JASCO). EI-MS spectra and HREI-MS spectra were recorded on a mass spectrometer (JMS-AX505HA, JEOL). The various NMR spectra were collected with a spectrometer (XL-400, Varian).

\section{Taxonomic Studies of the Producing Fungus}

For the taxonomic studies of fungus, Czapeck yeast extract agar (CYA), malt extract agar (MEA), Czapeck yeast extract agar with $20 \%$ sucrose (CY20S) were used. Taxonomic studies and identification were conducted according to the procedures described by Klich [11] Morphological observations were done under a light microscope (Vanox-S AH-2, Olympus) and a scanning electron microscope (JSM-5600, JEOL). Color names and hue numbers were determined according to the Color Harmony Manual [12].

\section{Assay for Potentiating Activity of Imipenem against MRSA}

MRSA K-24, a clinical isolate, was used and anti-MRSA activity was measured by two methods. 1) Paper disk method; MRSA was cultured in Mueller-Hinton broth (MHB, Difco) at $37^{\circ} \mathrm{C}$ for 20 hours and adjusted to $1 \times 10^{8}$ $\mathrm{CFU} / \mathrm{ml}$. The inoculum $(100 \mu \mathrm{l})$ was spread on MHA medium in a plate $(10 \times 14 \mathrm{~cm}$, Eiken Kizai) containing MHB and $1.5 \%$ of agar (Shimizu Shokuhin) with or without imipenem $(10 \mu \mathrm{g} / \mathrm{ml})$, whose concentration has no effect on growth of MRSA. Paper disks (Advantec) containing various amounts of a sample were placed on the MHA plate and incubated at $37^{\circ} \mathrm{C}$ for 20 hours. AntiMRSA activity was expressed as the diameter $(\mathrm{mm})$ of the inhibitory zone on the MHA plate. 2) Liquid microdilution method [13]; after MHB ( $85 \mu \mathrm{l})$ was added to each well of a 96-well microplate (Corning), a sample dissolved in methanol $(5 \mu \mathrm{l})$ was added to the final concentration as indicated ( $4 \mu \mathrm{g} / \mathrm{ml}$ for stemhpone $\mathrm{C}$ as described below). Then imipenem, or other antimicrobial agents dissolved in distilled water $(5 \mu \mathrm{l})$, were added to each well to a final concentration of 0.15 to $512 \mu \mathrm{g} / \mathrm{ml}$. Finally, MRSA $(5 \mu \mathrm{l})$ was added at a concentration of $1 \times 10^{7} \mathrm{CFU} / \mathrm{ml}$. Microplates were incubated at $37^{\circ} \mathrm{C}$ for 20 hours without shaking. MIC is defined as the lowest concentration of an antimicrobial agent where MRSA cannot grow. 


\section{Other Biological Assays}

Antimicrobial activity against 15 species of microorganisms was measured by the paper disk method. The microorganisms were as follows; Bacillus subtilis ATCC 6633, Staphylococcus aureus FDA 209P, Micrococcus luteus PCI 1001, Mycobacterium smegmatis ATCC 607, Escherichia coli NIHJ, E. coli NIHJJ-2 IFO 12734, Pseudomonas aeruginosa IFO3080, Xanthomonas campestris pv. oryzae, Bacteroides fragilis ATCC 23745, Acholeplasma laidlawii PG8, Pyricularia oryzae KF 180, Aspergillus niger ATCC6275, Mucor racemosus IFO4581, Candida albicans and Saccharomyces cerevisiae. Media for microorganisms were as follows: GAM agar (Nissui Seiyaku) for B. fragilis; Bacto PPLO agar (Difco) supplemented with horse serum $15 \%$, glucose $0.1 \%$, phenol red $0.25 \%$ and agar $1.5 \%$ for $A$. laidlawii; Nutrient agar (Difco) for the other bacteria; a medium composed of glucose $1.0 \%$, yeast extract $0.5 \%$ and agar $0.8 \%$ for fungi and yeasts. A paper disk (i.d. $6 \mathrm{~mm}$, Advantec) containing $10 \mu \mathrm{g}$ of sample was placed on an agar plate. Bacteria except $X$. oryzae were incubated at $37^{\circ} \mathrm{C}$ for 24 hours. Yeasts and $X$. oryzae were incubated at $27^{\circ} \mathrm{C}$ for 24 hours. Fungi were incubated at $27^{\circ} \mathrm{C}$ for 48 hours. Antimicrobial activity was expressed as diameter $(\mathrm{mm})$ of the inhibitory zone.

\section{Results}

\section{Taxonomy of the Producing Fungus}

Colonies on CYA were $60 \sim 65 \mathrm{~mm}$ diameter after 7 days at $25^{\circ} \mathrm{C}$, floccose to velutinous, radically sulcate, white (a) to light ivory ( $2 \mathrm{ca}$ ) in color. The reverse side was cover tan (2ge). Colonies on MEA were $40 \sim 45 \mathrm{~mm}$ diameter, floccose to velutinous, light ivory (2ca) to bamboo $(2 \mathrm{gc})$. The reverse side was biscuit ecru (2ec). Colonies on
CY20S were $65 \sim 70 \mathrm{~mm}$ diameter, floccose to velutinous, radically sulcate, white (a) to light ivory (2ca). The reverse side was light wheat (2ea). At $5^{\circ} \mathrm{C}$ and $37^{\circ} \mathrm{C}$, no colonies were observed on CYA. Soluble pigment was produced on CY20S and light $\tan (3 \mathrm{gc})$ in color. Conidiogenesis on each medium was moderate to abundant. Conidiophores arose from foot cells and were $175 \sim 1500 \mu \mathrm{m}$ long. They were almost rough-walled and hyaline to slightly ivory. Vesicles were globose to subglobose and $15 \sim 60 \mu \mathrm{m}$ in diameter. Aspergilla (as shown in Figs. 2A and $2 \mathrm{~B}$ ) were biseriate and formed metulae and phialides. Metulae covered the entire surface of the vesicle, were cylindrical and $6 \sim 12 \times$ $3 \sim 6 \mu \mathrm{m}$ in size. Phialides were flask-shaped and $5 \sim 10 \times 2 \sim 3 \mu \mathrm{m}$ in size. Conidia (as shown in Fig. $2 \mathrm{C}$ ) were globose to subglobose with finely roughened walls and $2 \sim 4 \mu \mathrm{m}$ in size.

From the above characteristics, strain FKI-2136 was considered to belong to the genus Aspergillus and named Aspergillus sp. FKI-2136. The strain was deposited at the National Institute of Bioscience and Human-Technology, Agency of Industrial Science and Technology Japan, as NITE BP-83.

\section{Fermentation}

A slant culture of the strain FKI-2136 grown on LCA (glycerol $0.1 \%, \mathrm{KH}_{2} \mathrm{PO}_{4} 0.08 \%, \mathrm{~K}_{2} \mathrm{HPO}_{4} 0.02 \%, \mathrm{MgSO}_{4}$. $7 \mathrm{H}_{2} \mathrm{O} 0.02 \%, \mathrm{KCl} 0.02 \%, \mathrm{NaNO}_{3} 0.2 \%$, yeast extract $0.02 \%$, agar $1.5 \%, \mathrm{pH} 6.0$ ) was used to inoculate a $50-\mathrm{ml}$ tube containing $10 \mathrm{ml}$ of the seed medium (glucose $2.0 \%$, polypeptone $0.5 \%, \mathrm{MgSO}_{4} \cdot 7 \mathrm{H}_{2} \mathrm{O} 0.05 \%$, yeast extract $0.2 \%, \mathrm{KH}_{2} \mathrm{PO}_{4} 0.1 \%$, agar $0.1 \%, \mathrm{pH} 6.0$ ). The tube was shaken on a reciprocal shaker at $27^{\circ} \mathrm{C}$ for 2 days. A one-ml portion of the seed culture was then inoculated into a 500 $\mathrm{ml}$ Erlenmeyer flask containing $100 \mathrm{ml}$ of the production medium (glucose $1.0 \%$, soluble starch $2.0 \%$, soy bean oil $2.0 \%$, pharmamedia $1.0 \%$, meat extract $0.5 \%, \mathrm{MgSO}_{4}$
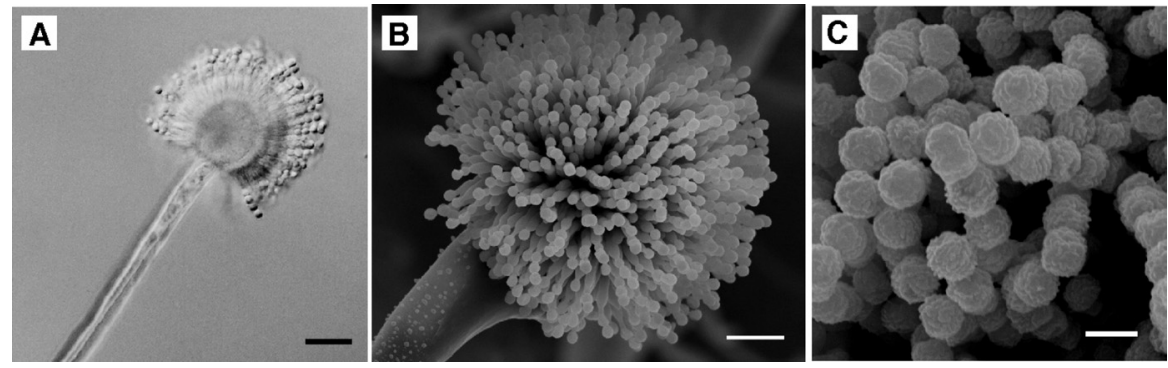

Fig. 2 Morphological observation of fungal strain FKI-2136.

(A) Conidial head under a light microscope (scale bar: $20 \mu \mathrm{m}$ ).

(B) Biseriate aspergilla under a scanning electron microscope (scale bar: $10 \mu \mathrm{m}$ ).

(C) Conidia under a scanning electron microscope (scale bar: $2 \mu \mathrm{m}$ ). 
$7 \mathrm{H}_{2} \mathrm{O} 0.1 \%, \mathrm{CaCO}_{3} 0.3 \%$, trace salt solutions $\left(\mathrm{FeSO}_{4}\right.$. $7 \mathrm{H}_{2} \mathrm{O} \quad 0.1 \%, \mathrm{MnCl}_{2} \cdot 4 \mathrm{H}_{2} \mathrm{O} \quad 0.1 \%, \mathrm{ZnSO}_{4} \cdot 7 \mathrm{H}_{2} \mathrm{O} \quad 0.1 \%$, $\left.\mathrm{CuSO}_{4} \cdot 5 \mathrm{H}_{2} \mathrm{O} 0.1 \%, \mathrm{CoCl}_{2} \cdot 6 \mathrm{H}_{2} \mathrm{O} 0.1 \%\right) 1.0 \%$, agar $0.1 \%$, $\mathrm{pH}$ 6.0). The fermentation was carried out at $27^{\circ} \mathrm{C}$ for 11 days. Stemphones B and C and cochlioquinone D were detected in the culture broth from day 2 to day 3 after inoculation. Stemphone B and cochlioquinone D reached a maximal level (230 and $109 \mu \mathrm{g} / \mathrm{ml}$, respectively) on day 5, and the titers gradually decreased until day 11 . On the other hand, stemphone $\mathrm{C}$ reached a maximal level $(1.1 \mathrm{mg} / \mathrm{ml})$ on day 11 .

\section{Isolation}

The 11-day old whole broth (1 liter) was centrifuged at $3000 \mathrm{rpm}$ for 10 minutes. The mycelium was extracted with acetone (1.5 liters). After the acetone extracts were filtered and concentrated to remove acetone, the aqueous residue was extracted with ethyl acetate. The extracts were dried over $\mathrm{Na}_{2} \mathrm{SO}_{4}$ and concentrated in vacuo to dryness to yield crude materials $(4.4 \mathrm{~g})$. The materials were dissolved in $\mathrm{CHCl}_{3}$, applied on a silica gel column $(59 \mathrm{~g})$, and eluted stepwise with $2: 1(\mathrm{v} / \mathrm{v})$ of hexane - EtOAc solvent and $100: 0,100: 1,50: 1,10: 1$ and $1: 1(\mathrm{v} / \mathrm{v})$ of $\mathrm{CHCl}_{3}$ $\mathrm{CH}_{3} \mathrm{OH}$ solvents $(120 \mathrm{ml}$ for each solvent). The $10: 1$ fraction $\left(\mathrm{CHCl}_{3}-\mathrm{CH}_{3} \mathrm{OH}\right)$ showing the activity was concentrated to give a red brown oily material $(786 \mathrm{mg})$, which was subjected to a second silica gel column $(50 \mathrm{~g})$. The material was eluted with $100: 1,50: 1,20: 1,10: 1$ and $5: 1(\mathrm{v} / \mathrm{v})$ of $\mathrm{CHCl}_{3}-\mathrm{CH}_{3} \mathrm{OH}$ solvents $(12 \mathrm{ml} \times 10$ tubes for each solvent). The first active fraction from the 2 nd tube of $100: 1$ to the 3 rd tube of $50: 1\left(\mathrm{CHCl}_{3}-\mathrm{CH}_{3} \mathrm{OH}\right)$ was collected and concentrated to give a red brown oil (274 $\mathrm{mg}$ ). The oil containing enriched stemphone $\mathrm{C}$ was finally purified with preparative HPLC (column; PEGASIL ODS (Senshu Sci. Co.), $20 \times 250 \mathrm{~mm}$; solvent, $70 \% \mathrm{CH}_{3} \mathrm{CN}$; detection, $\mathrm{UV}$ at $210 \mathrm{~nm}$; flow rate, $6.0 \mathrm{ml} /$ minute). Under these conditions, cochlioquinone $\mathrm{D}$ and stemphone $\mathrm{C}$ were eluted as peaks with retention times of 23 and 28 minutes, respectively (Fig. 3A). Each pooled fraction was concentrated in vacuo to dryness to give pure stemphone $\mathrm{C}$ $(174 \mathrm{mg})$ and cochlioquinone $\mathrm{D}(42 \mathrm{mg})$ as yellow materials. The second active fraction from the 4th tube of $50: 1$ to the 3 rd tube of $20: 1\left(\mathrm{CHCl}_{3}-\mathrm{CH}_{3} \mathrm{OH}\right)$ containing stemphone $\mathrm{B}$ was also purified by HPLC (column; PEGASIL ODS, $20 \times 250 \mathrm{~mm}$; solvent, $55 \% \mathrm{CH}_{3} \mathrm{CN}$, UV at $210 \mathrm{~nm}$; flow rate, $9 \mathrm{ml} /$ minute). Stemphone B was eluted as a peak with a retention time of 20 minutes (Fig. 3B). The fraction was concentrated in vacuo to dryness to yield pure stemphone B $(58 \mathrm{mg})$ as a yellow material.
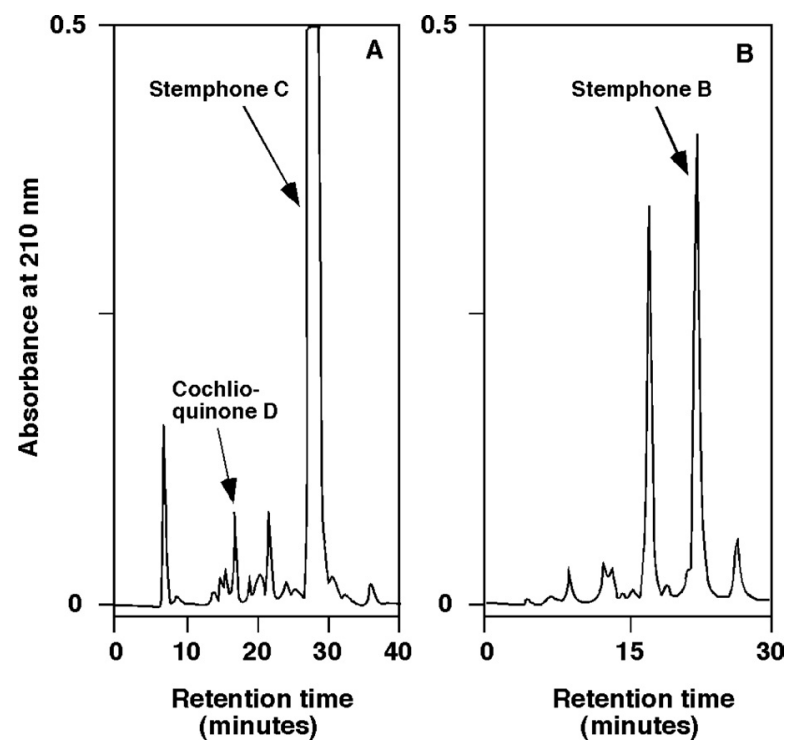

Fig. 3 Chromatographic profiles of isolation of stemphones by HPLC.

(A) Stemphone C and choclioquinone D. Column, PEGASIL ODS $20 \times 250 \mathrm{~mm}$; solvent $70 \%$ aq acetonitrile; detection, UV at $210 \mathrm{~nm}$; flow rate, $6.0 \mathrm{ml} /$ minute; sample, $100 \mathrm{mg}$ of active materials (obtained through second silica gel column chromatography) dissolved in $50 \mu$ l methanol was injected.

(B) Stemphone B. Column, PEGASIL ODS $20 \times 250 \mathrm{~mm}$; solvent $55 \%$ aq acetonitrile; detection, UV at $210 \mathrm{~nm}$; flow rate, 9.0 $\mathrm{ml} /$ minute; sample, $100 \mathrm{mg}$ of active materials (obtained through second silica gel column chromatography) dissolved in $50 \mu \mathrm{l}$ methanol was injected.

Table 1 Physico-chemical properties of stemphones B and $\mathrm{C}$

\begin{tabular}{lcc}
\hline & Stemphone B & Stemphone C \\
\hline Appearance & Yellow powder & Yellow powder \\
Molecular weight & 546 & 514 \\
Molecular formula & $\mathrm{C}_{30} \mathrm{H}_{42} \mathrm{O}_{9}$ & $\mathrm{C}_{30} \mathrm{H}_{42} \mathrm{O}_{7}$ \\
HREI-MS $(\mathrm{m} / z)$ & & \\
Calcd.: & $546.2835\left(\mathrm{M}^{+}\right)$ & $514.2926\left(\mathrm{M}^{+}\right)$ \\
Found: & 546.2829 & 514.2931 \\
UV (MeOH) $\lambda_{\max } \mathrm{nm}(\varepsilon)$ & $206(7748)$, & $207(7604)$, \\
& $267(5154)$, & $265(7239)$, \\
{$[\alpha]_{D}^{26}$} & $383(505)$ & $398(616)$ \\
IR $(\mathrm{KBr}) v_{\max }\left(\mathrm{cm}^{-1}\right)$ & $+144.0^{\circ}$ & $+94.6^{\circ}$ \\
& $(c=0.1, \mathrm{MeOH})$ & $(c=0.1, \mathrm{MeOH})$ \\
& 1740,2935, & 3444,2944, \\
& 1602 & 1739,1643, \\
& & 1604 \\
\hline
\end{tabular}




\section{Physico-chemical Properties of Stemphones}

Physico-chemical properties of stemphones are summarized in Table 1. They showed similar UV absorption maxima at 265 to $267 \mathrm{~nm}$. The IR absorption at $3444 \sim 2935$ and $1739 \sim 1602 \mathrm{~cm}^{-1}$ suggested the presence of hydroxy and carbonyl groups in the structures.

\section{Structure Elucidation of Stemphone B}

The molecular formula of stemphone $\mathrm{B}$ was determined to be $\mathrm{C}_{30} \mathrm{H}_{42} \mathrm{O}_{9}$ on the basis of HREI-MS measurement. The ${ }^{13} \mathrm{C}$ NMR spectrum (in $\mathrm{CDCl}_{3}$ ) showed 30 resolved signals, which were classified into eight methyl carbons, three methylene carbons, two $s p^{3}$ methine carbons, two $s p^{2}$ methine carbons, five oxygenated $s p^{3}$ methine carbons, one $s p^{3}$ quaternary carbon, two oxygenated $s p^{3}$ quaternary carbons, four $s p^{2}$ quaternary carbons and three carbonyl carbons by analysis of the DEPT spectra. The ${ }^{1} \mathrm{H}$ NMR spectrum (in $\mathrm{CDCl}_{3}$ ) displayed 41 proton signals, two of which were suggested to be hydroxy protons ( $\delta 3.42$ and $\delta$ 4.13). Taking the molecular formula into consideration, the presence of another hydroxy proton was suggested. The connectivity of proton and carbon atoms was established by

Table $2{ }^{1} \mathrm{H}$ and ${ }^{13} \mathrm{C}$ NMR chemical shifts of stemphones $\mathrm{B}$ and $\mathrm{C}$ and cochlioquinone $\mathrm{D}$

\begin{tabular}{|c|c|c|c|c|c|c|}
\hline \multirow[b]{2}{*}{ Position } & \multicolumn{2}{|c|}{ Stemphone B } & \multicolumn{2}{|c|}{ Stemphone C } & \multicolumn{2}{|c|}{ Cochlioquinone D } \\
\hline & $\delta_{\mathrm{C}}$ & $\delta_{\mathrm{H}}(\mathrm{J} \mathrm{Hz})$ & $\delta_{\mathrm{C}}$ & $\delta_{\mathrm{H}}(\mathrm{J} \mathrm{Hz})$ & $\delta_{\mathrm{C}}$ & $\delta_{\mathrm{H}}(\mathrm{JHz})$ \\
\hline 1 & $13.2 \mathrm{q}$ & $1.61 \mathrm{~d}, \mathrm{br}(7.0)$ & $13.1 \mathrm{q}$ & $1.59 \mathrm{~d}, \mathrm{br}(7.0)$ & $15.0 \mathrm{q}$ & $1.87 \mathrm{~d}(7.0)$ \\
\hline 2 & $125.3 d$ & 5.56 q, br (7.0) & $124.9 \mathrm{~d}$ & $5.53 \mathrm{q}(7.0)$ & $138.6 \mathrm{~d}$ & $6.86 q(7.0)$ \\
\hline 3 & $131.7 \mathrm{~s}$ & - & $132.1 \mathrm{~s}$ & - & $136.8 \mathrm{~s}$ & - \\
\hline 4 & $81.4 d$ & $5.15 \mathrm{~d}(8.5)$ & $81.5 d$ & $5.14 \mathrm{~d}(8.5)$ & $200.5 s$ & - \\
\hline 5 & $34.2 d$ & $3.30 \mathrm{dq}(8.5,7.0)$ & $33.5 \mathrm{~d}$ & $3.34 \mathrm{dq}(8.5,7.0)$ & $37.6 \mathrm{~d}$ & $4.62 q(7.0)$ \\
\hline 6 & $148.8 \mathrm{~s}$ & - & $148.0 \mathrm{~s}$ & - & $146.5 \mathrm{~s}$ & - \\
\hline 7 & $181.0 \mathrm{~s}$ & - & $181.3 \mathrm{~s}$ & - & $181.4 \mathrm{~s}$ & - \\
\hline 8 & $151.5 \mathrm{~s}$ & - & $152.3 \mathrm{~s}$ & - & $152.1 \mathrm{~s}$ & - \\
\hline 9 & $117.8 \mathrm{~s}$ & - & $117.8 \mathrm{~s}$ & - & $118.4 \mathrm{~s}$ & - \\
\hline 10 & $188.5 \mathrm{~s}$ & - & $187.1 \mathrm{~s}$ & - & $186.8 \mathrm{~s}$ & - \\
\hline 11 & $132.6 \mathrm{~d}$ & $6.47 \mathrm{~s}$ & $132.4 d$ & $6.48 \mathrm{~d}(1.0)$ & $133.2 \mathrm{~d}$ & $6.51 \mathrm{~d}(1.0)$ \\
\hline \multirow[t]{2}{*}{12} & $62.3 \mathrm{~d}$ & $4.90 \mathrm{~d}(11.0)$ & $16.4 \mathrm{t}$ & $2.11 \mathrm{dd}(19.0,13.0)$ & $16.5 \mathrm{t}$ & $2.13 \mathrm{dd}(19.0,13.0)$ \\
\hline & & & & $2.52 \mathrm{dd}(19.0,5.0)$ & & $2.52 \mathrm{dd}(19.0,5.0)$ \\
\hline $12-\mathrm{OH}^{\mathrm{a}}$ & - & $3.42, \mathrm{br}$ & - & - & - & - \\
\hline 13 & $45.4 d$ & $2.23 \mathrm{~d}(11.0)$ & $46.6 \mathrm{~d}$ & $1.43 \mathrm{dd}(13.0,5.0)$ & $46.5 d$ & $1.44 \mathrm{dd}(13.0,5.0)$ \\
\hline 14 & $83.8 \mathrm{~s}$ & - & $80.5 \mathrm{~s}$ & - & $80.6 \mathrm{~s}$ & - \\
\hline 15 & $37.1 \mathrm{t}$ & $1.88 \mathrm{~m}, 2.08 \mathrm{~m}$ & $37.2 \mathrm{t}$ & $1.79 \mathrm{~m}, 2.18 \mathrm{~m}$ & $37.2 \mathrm{t}$ & $1.80 \mathrm{~m}, 2.13 \mathrm{~m}$ \\
\hline 16 & $25.0 \mathrm{t}$ & 1.58 m, 1.86 m & $25.2 \mathrm{t}$ & 1.63 m, 1.80 m & $25.2 \mathrm{t}$ & $1.80 \mathrm{~m}$ \\
\hline 17 & $76.2 d$ & $3.68 \mathrm{dd}(13.0,4.0)$ & $84.0 \mathrm{~d}$ & $3.12 \mathrm{dd}(12.0,4.0)$ & $84.0 d$ & $3.12 \mathrm{dd}(12.0,3.5)$ \\
\hline 18 & $40.8 \mathrm{~s}$ & - & $35.5 \mathrm{~s}$ & - & $35.5 \mathrm{~s}$ & - \\
\hline 19 & $70.7 d$ & $4.10 \mathrm{t}, \mathrm{br}(3.0)$ & $36.8 \mathrm{t}$ & $1.21 \mathrm{~m}, 1.86 \mathrm{~m}$ & $36.8 t$ & $1.20 \mathrm{~m}, 1.92 \mathrm{~m}$ \\
\hline $19-\mathrm{OH}^{\mathrm{a}}$ & - & $4.13, \mathrm{br}$ & - & - & - & - \\
\hline 20 & $28.2 \mathrm{t}$ & 1.60 m, 1.96 m & $21.3 t$ & 1.48 m, 1.66 m & $21.3 t$ & $1.48 \mathrm{~m}$ \\
\hline 21 & $79.6 d$ & $3.57 \mathrm{dd}(13.0,3.0)$ & $84.9 d$ & $3.21 \mathrm{dd}(12.0,3.0)$ & $84.9 d$ & 3.22 dd $(12.0,3.0)$ \\
\hline 22 & $71.7 \mathrm{~s}$ & - & $71.8 \mathrm{~s}$ & - & $71.8 \mathrm{~s}$ & - \\
\hline 23 & $23.8 \mathrm{q}$ & $1.14 \mathrm{~s}$ & $23.8 \mathrm{q}$ & $1.16 \mathrm{~s}$ & $23.8 \mathrm{q}$ & $1.17 \mathrm{~s}$ \\
\hline 24 & $26.4 \mathrm{q}$ & $1.20 \mathrm{~s}$ & $26.1 \mathrm{q}$ & $1.18 \mathrm{~s}$ & $26.1 \mathrm{q}$ & $1.19 \mathrm{~s}$ \\
\hline 25 & $13.1 \mathrm{q}$ & $0.98 \mathrm{~s}$ & $12.2 \mathrm{q}$ & $0.88 \mathrm{~s}$ & $12.2 \mathrm{q}$ & $0.89 \mathrm{~s}$ \\
\hline 26 & $21.3 q$ & $1.32 \mathrm{~s}$ & $20.8 q$ & $1.28 \mathrm{~s}$ & $20.8 q$ & $1.27 \mathrm{~s}$ \\
\hline 27 & $16.9 q$ & $1.04 \mathrm{~d}(7.0)$ & $17.0 \mathrm{q}$ & $1.02 \mathrm{~d}(7.0)$ & $16.4 \mathrm{q}$ & $1.27 \mathrm{~d}(7.0)$ \\
\hline 28 & $11.6 q$ & $1.62 \mathrm{~s}$ & $11.6 \mathrm{q}$ & $1.62 \mathrm{~s}, \mathrm{br}$ & $11.5 q$ & $1.77 \mathrm{~s}, \mathrm{br}$ \\
\hline 29 & $169.7 \mathrm{~s}$ & - & $169.7 \mathrm{~s}$ & - & & \\
\hline 30 & $21.2 \mathrm{q}$ & $1.94 \mathrm{~s}$ & $21.1 \mathrm{q}$ & $1.93 \mathrm{~s}$ & & \\
\hline
\end{tabular}

a Exchangeable signals. 


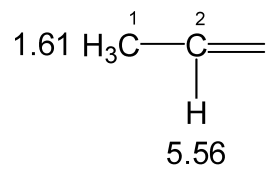

I

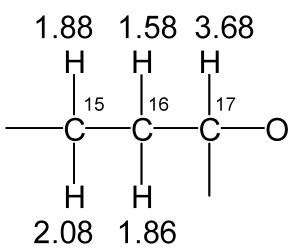

IV

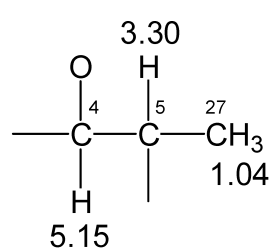

II

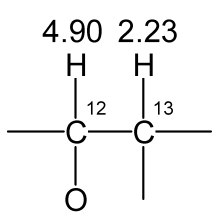

III

Fig. 4 Partial structures of stemphone B.

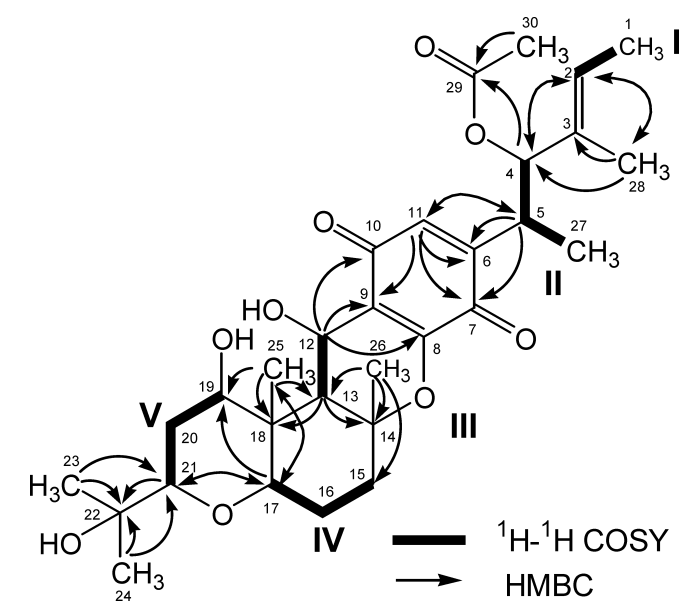

Fig. $5{ }^{1} \mathrm{H}-{ }^{1} \mathrm{H}$ COSY and ${ }^{13} \mathrm{C}-{ }^{1} \mathrm{H}$ HMBC experiments of stemphone B.

the ${ }^{13} \mathrm{C}-{ }^{1} \mathrm{H}$ HMQC spectrum (Table 2). Analyses of the ${ }^{1} \mathrm{H}-$ ${ }^{1} \mathrm{H}$ COSY revealed the presence of five partial structures I to $\mathrm{V}$ as shown in Fig. 4. Furthermore, ${ }^{13} \mathrm{C}-{ }^{1} \mathrm{H}$ long range couplings of ${ }^{2} J$ and ${ }^{3} J$ observed in the ${ }^{13} \mathrm{C}-{ }^{1} \mathrm{H}$ HMBC spectrum (Fig. 5) gave the following linkages: 1$)$ The cross peaks from $\mathrm{H}_{3}-28(\delta 1.62)$ to $\mathrm{C}-2(\delta 125.3), \mathrm{C}-3(\delta 131.7)$ and C-4 $(\delta 81.4)$, and from $\mathrm{H}-4(\delta 5.15)$ to $\mathrm{C}-2$ showed the connection between the partial structures I and II. 2) The cross peaks from $\mathrm{H}-4$ and $\mathrm{H}_{3}-30(\delta 1.94)$ to $\mathrm{C}-29(\delta 169.7)$ showed that an acetoxy group was connected to the C-4 oxygenated methine carbon, indicating the presence of a side chain containing an acetoxy group and the partial structures I and II. 3$)$ The cross peaks from H-5 $(\delta 3.30)$ to C-6 $(\delta$ 148.8), C-7 $(\delta 181.0)$ and C-11 $(\delta$ 132.6), from H$11(\delta 6.47)$ to $\mathrm{C}-5(\delta 34.2), \mathrm{C}-6, \mathrm{C}-7$ and $\mathrm{C}-9(\delta 117.8)$, and from $\mathrm{H}-12(\delta 4.90)$ to $\mathrm{C}-8(\delta 151.5), \mathrm{C}-9$ and C-10 $(\delta$ $188.5)$ showed the presence of a quinone skeleton, which was also supported by the chemical shifts of C-7 and C-10, and UV $[10,14,15] .4)$ The cross peaks from $\mathrm{H}_{3}-26(\delta$ $1.32)$ to $\mathrm{C}-13(\delta 45.4), \mathrm{C}-14(\delta 83.8)$ and $\mathrm{C}-15(\delta 37.1)$, from $\mathrm{H}-13$ to $\mathrm{C}-14$ and $\mathrm{C}-18(\delta 40.8)$, from $\mathrm{H}_{3}-25(\delta 0.98)$ to $\mathrm{C}-13, \mathrm{C}-17$ ( $\delta 76.2), \mathrm{C}-18$ and $\mathrm{C}-19(\delta 70.7)$, and from $\mathrm{H}-17$ ( $\delta$ 3.68) to $\mathrm{C}-19$ and $\mathrm{C}-21$ ( $\delta$ 79.6) showed the connection from the partial structures III to V. Taking the degree of unsaturation into consideration, a tetracyclic structure containing the quinone ring should be formed as shown in Fig. 5. Further, the chemical shifts of C-8, C-14, $\mathrm{C}-17$ and $\mathrm{C}-21$ correspond to the values of oxygenated carbons, indicating that the tetracyclic structure contains two tetrahydropyran rings. 5) The cross peaks from $\mathrm{H}_{3}-23$ $(\delta 1.14)$ and $\mathrm{H}_{3}-24(\delta 1.20)$ to $\mathrm{C}-21$ and $\mathrm{C}-22(\delta 71.7)$, and the chemical shift of $\mathrm{C}-22$ showed the presence of a 2 hydroxypropyl group. These results satisfied the degree of unsaturation and the molecular formula. The chemical shifts of stemphone B were comparable to those of stemphone A except for C-19 [15]. Taken together, the structure of stemphone B was elucidated as shown in Fig. 1. The geometry of the double bond between C-2 and C-3 was determined to be $\mathrm{E}$ configuration because stemphone $\mathrm{B}$ shares the same chemical shifts of stemphone A [15].

\section{Structure Elucidation of Stemphone C}

The molecular formula $\mathrm{C}_{30} \mathrm{H}_{42} \mathrm{O}_{7}$ of stemphone $\mathrm{C}$ was two oxygen atoms smaller than stemphone $\mathrm{B}$. The ${ }^{1} \mathrm{H}$ NMR spectrum of stemphone $\mathrm{C}$ was similar to stemphone $\mathrm{B}$, but two signals corresponding to a hydroxy proton were missing. Correspondingly, two methylene carbon signals ( $\delta$ 16.4 and $\delta$ 36.8) were observed instead of the two 
oxygenated methine carbon signals for stemphone B by analysis of the ${ }^{13} \mathrm{C}$ NMR and DEPT spectrum. The position of the methylene carbons was determined by ${ }^{1} \mathrm{H}-{ }^{1} \mathrm{H}$ COSY and $\mathrm{HMBC}$ experiments as shown in Fig. 6. The cross peaks from $\mathrm{H}_{2}-12(\delta 2.11,2.52)$ to $\mathrm{C}-8(\delta 152.3)$, C-9 $(\delta$ $117.8), \mathrm{C}-10(\delta 187.1)$ and $\mathrm{C}-18(\delta 35.5)$ indicated that the carbon $(\delta 16.4)$ was the $\mathrm{C}-12$ position. The cross peaks from $\mathrm{H}-13(\delta 1.43), \mathrm{H}-17(\delta 3.12)$ and $\mathrm{H}-20(\delta 1.48,1.66)$ to $\mathrm{C}-19$ ( $\delta 36.8)$ indicated that the other one $(\delta 36.8)$ was the $\mathrm{C}-19$ position. The chemical shifts of stemphone $\mathrm{C}$ were comparable to those of stemphone A except for C-12 [15]. Taken together, the structure of stemphone $\mathrm{C}$ was elucidated as shown in Fig. 1.

\section{Biological Properties}

Potentiation of Imipenem Activity against MRSA by

Stemphones

By the paper disk assay, cochlioquinone $\mathrm{D}$, and stemphones

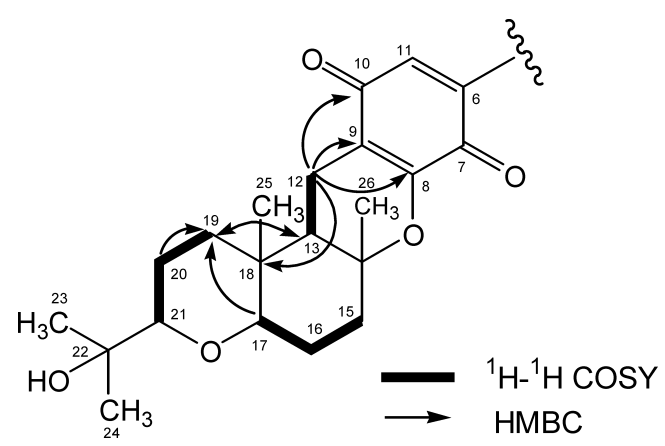

Fig. $6{ }^{1} \mathrm{H}-{ }^{1} \mathrm{H}$ COSY and ${ }^{13} \mathrm{C}-{ }^{1} \mathrm{H}$ HMBC experiments of stemphone $\mathrm{C}$.
$\mathrm{B}$ and $\mathrm{C}$ showed almost no anti-MRSA activity at least up to $50 \mu \mathrm{g} / 6 \mathrm{~mm}$ disk, but showed anti-MRSA activity on MHA plates containing imipenem $(10 \mu \mathrm{g} / \mathrm{ml})$ with inhibition zones of 9,15 and $20 \mathrm{~mm}$ at $5 \mu \mathrm{g} / 6 \mathrm{~mm}$ disk, respectively. Next, the potentiating effect of stemphone C on the activity of other typical antimicrobial agents against MRSA was investigated by the liquid microdilution method. First, the effect of stemphone $\mathrm{C}$ itself was tested on the growth of MRSA in this method, resulting in an MIC value of $16 \mu \mathrm{g} / \mathrm{ml}$. Therefore, the concentration of stemphone $\mathrm{C}$ was set up at $4 \mu \mathrm{g} / \mathrm{ml}(7.8 \mu \mathrm{M}$, one fourth of the MIC value, no effect on MRSA growth) to investigate the potentiating activity of the agents against MRSA. As summarized in Table 3, stemphone $\mathrm{C}$ markedly reduced the MIC value of imipenem from 16 to $0.03 \mu \mathrm{g} / \mathrm{ml}$ and that of cloxacillin from 512 to $1.0 \mu \mathrm{g} / \mathrm{ml}$, yielding 512 -fold potentiation of their activity. Cefazolin activity against MRSA was also enhanced in combination with stemphone C. On the other hand, other antimicrobial agents showed almost no effect or slight potentiation ( $1 \sim 4$-fold). These data suggested that stemphone $\mathrm{C}$ could potentiate $\beta$-lactam activity against MRSA.

Other Biological Activities

Stemphones B and C showed comparable antimicrobial activities against $B$. subtilis, S. aureus, M. luteus, and $A$. laidlawii, with almost the same inhibition zones of 9, 8, 14 and $9 \mathrm{~mm}$ at $5 \mu \mathrm{g} / 6 \mathrm{~mm}$ disk, respectively. On the other hand, cochlioquinone $\mathrm{D}$ showed a weak activity against only M. luteus with an inhibition zone of $8 \mathrm{~mm}$ at $5 \mu \mathrm{g} / 6$ mm disk.

Table 3 MIC values of various antimicrobial agents against MRSA in the absence or presence of stemphone $\mathrm{C}$

\begin{tabular}{lccc}
\hline & \multicolumn{2}{c}{ MIC $(\mu \mathrm{g} / \mathrm{ml})$} & Ratio \\
\cline { 2 - 3 } Antimicrobial agent & - & + stemphone C* & (-/+ stemphone C) \\
\cline { 2 - 3 } Imipenem & 16 & 1 & 512 \\
Cloxacillin & 512 & 4 & 512 \\
Cefazolin & 64 & 0.5 & 16 \\
Vancomycin & 0.5 & 0.5 & 1 \\
Streptomycin & 2 & 32 & 4 \\
Tetracycline & 32 & $>256$ & 1 \\
Erythromycin & 256 & 32 & 2 \\
Ciprofloxacin & 64 & & 1 \\
\hline
\end{tabular}

* Concentration of stemphone $\mathrm{C}$ is $4 \mu \mathrm{g} / \mathrm{ml}$. 


\section{Discussion}

Stemphones and cochlioquinones, both of fungal origin, are structurally related by having a tetracyclic quinone skeleton in common. Compounds of stemphone family have been reported to show various biological activities including: nematocidal activity of cochlioquinone A [16]; inhibitory activity against diacylglycerol acyltransferase by cochlioquinones [17]; and inhibitory activity against cholesterol acyltransferase by epi-cochlioquinone [18]. In this report, we showed that stemphones $\mathrm{B}$ and $\mathrm{C}$ as well as cochlioquinone D exhibited activity as potentiator of $\beta$-lactam imipenem against MRSA. Among these compounds, stemphone $\mathrm{C}$ was the most potent followed by stemphone B. Cochlioquinone D showed only moderate activity. These results indicated that the acetoxyl residue at C-4 is important for the potentiating activity. The relationships of different biological activities exhibited by the stemphone family remain to be established.

Several natural products are known to potentiate $\beta$ lactam activity against MRSA. Polyoxotungstates were reported to show the activity possibly due to inhibition of penicillin binding proteins (PBPs) and $\beta$-lactamase [19]. Polyphenols such as epigallocatechin gallate isolated from tea [20], corilagin [21] and tellimagrandin I [22] were also reported to show the activity. They were considered to inhibit the function of PBP2' and suppress $\beta$-lactamase activity [23]. The potentiating activity of various $\beta$-lactams against MRSA by stemphone and the mechanism of the potentiation activity are under investigation and will be published in the near future.

Acknowledgments This study was supported in part by the grant of the 21st Century COE Program, Ministry of Education, Culture, Sports, Science and Technology, Japan. We thank Dr. H. Hanaki for providing us with the MRSA clinical strain. We express our thanks to Ms. N. Sato for NMR experiments, Ms. T. Sakabe and Ms. A. Nakagawa for mass spectra.

\section{References}

1. Hiramatsu K, Hanaki H, Ino T, Yabuta K, Oguri T, Tenover FC. Methicillin-resistant Staphylococcus aureus clinical strain with reduced vancomycin susceptibility. J Antimicrob Chemother 40: 135-136 (1997)

2. Centers for Disease Control and Prevention. Staphylococcus aureus with reduced susceptibility to vancomycin-United States, 1997. MMWR Morb Mortal Wkly Rep 46: 765-766 (1997)

3. Ōmura S. Antiinfective drugs into the 21st century. Nippon
Saikingaku Zasshi 54: 795-813 (1999) (in Japanese)

4. Fukuda T, Arai M, Yamaguchi Y, Masuma R, Tomoda H, Ōmura S. New beauvericines, potentiators of antifungal miconazole activity, produced by Beauveria sp. FKI-1366. I. Taxonomy, fermentation, isolation and biological properties. J Antibiot 57: 110-116 (2004)

5. Fukuda T, Arai M, Tomoda H, Ōmura S. New beauvericines, potentiators of antifungal miconazole activity, produced by Beauveria sp. FKI-1366. II. Structure elucidation. J Antibiot 57: 117-124 (2004)

6. Fukuda T, Matsumoto A, Takahashi Y, Tomoda H, Ōmura S. Phenatic acids $\mathrm{A}$ and $\mathrm{B}$, new potentiators of antifungal miconazole activity produced by Streptomyces sp. K030132. J Antibiot 58: 252-259 (2005)

7. Fukuda T, Yamaguchi Y, Masuma R, Tomoda H, Ōmura S. Citridones, new potentiators of antifungal miconazole activity, produced by Penicillium sp. FKI-1938. I. Taxonomy, fermentation, isolation and biological properties. J Antibiot 58: 309-314 (2005)

8. Fukuda T, Tomoda H, Ōmura S. Citridones, new potentiators of antifungal miconazole activity, produced by Penicillium sp. FKI-1938. II. Structure elucidation. J Antibiot 58: 315321 (2005)

9. Lim CH, Miyagawa H, Ueno T, Takenaka H, Tsurusima T. Isolation and structure elucidation of terpenoid phytotoxins produced by the plant pathogenic fungus Bipolaris cynodontis. Tennen Yuki Kagobutsu Toronkai Koen Yoshishu 37: 325-330 (1995)

10. Scott PM, Lawrence JW. Stemphone, a biologically active yellow pigment produced by Stemphylium sarcinaeforme (Cav.) Wiltshire. Can J Microbiol 14: 1015-1016 (1968)

11. Klich MA. Identification of common Aspergillus species. Centraalbureau voor Schimmelcultures, Utrecht (2002)

12. Jacobson E, Granville WC, Foss CE. Color Harmony Manual, 4th ed. Container of America, Chicago (1958)

13. Committee for Antimicrobial Susceptibility Testing Method. Standard methods of Japanese Society of Chemotherapy. Chemotherapy 38: 102-105 (1990) (in Japanese)

14. Huber C, Court WA, Devlin JP, Edwards OE, Scott PM. Stemphone, a new type of natural quinone. Tetrahedron Lett 29: 2545-2548 (1974)

15. Miyagawa H, Nagai S, Tsurushima $T$, Sato $M$, Ueno $T$, Fukami H. Phytotoxins produced by the plant pathogenic fungus Bipolaris bicolor El-1. Biosci Biotech Biochem 58: 1143-1145 (1994)

16. Schaeffer JM, Frazier EG, Bergstrom AR, Williamson JM, Liesch JM, Goetz MA. Cochlioquinone A, a nematocidal agent which competes for specific $\left[{ }^{3} \mathrm{H}\right]$ ivermectin binding sites. J Antibiot 43: 1179-1182 (1990)

17. Lee HB, Lim CH, Kwon HJ, Kim YK, Lee HS, Kim CJ. Inhibitory activity of diacylglycerol acyltransferase by cochlioquinones A and A1. J Antibiot 56: 967-969 (2003)

18. Fujioka T, Yao K, Hamano K, Hosoya T, Kagasaki T, Furukawa Y, Haruyama H, Sato S, Koga T, Tsujita Y. Epi-cochlioquinone A, a novel acyl-CoA:cholesterol 
acyltransferase inhibitor produced by Stachybotrys bisbyi. J Antibiot 49: 409-413 (1996)

19. Yamase T, Fukuda N, Tajima Y. Synergistic effect of polyoxotungstates in combination with beta-lactam antibiotics on antibacterial activity against methicillinresistant Staphylococcus aureus. Biol Pharm Bull 19: 459465 (1996)

20. Zhao WH, Hu ZQ, Okubo S, Hara Y, Shimamura T. Mechanism of synergy between epigallocatechin gallate and beta-lactams against methicillin-resistant Staphylococcus aureus. Antimicrob Agents Chemother 45: 1737-1742 (2001)

21. Shimizu M, Shiota S, Mizushima T, Ito H, Hatano T, Yoshida T, Tsuchiya T. Marked potentiation of activity of beta-lactams against methicillin-resistant Staphylococcus aureus by corilagin. Antimicrob Agents Chemother 45: 3198-3201 (2001)

22. Shiota S, Shimizu M, Mizushima T, Ito H, Hatano T, Yoshida T, Tsuchiya T. Restoration of effectiveness of betalactams on methicillin-resistant Staphylococcus aureus by tellimagrandin I from rose red. FEMS Microbiol Lett 185: 135-138 (2000)

23. Shiota S, Shimizu M, Sugiyama J, Morita Y, Mizushima T, Tsuchiya T. Mechanisms of action of corilagin and tellimagrandin I that remarkably potentiate the activity of beta-lactams against methicillin-resistant Staphylococcus aureus. Microbiol Immunol 48: 67-73 (2004) 